\title{
The Role of Visual Aids in Corporate Annual Reports in Drawing Wider Audience Internally
}

\author{
Mochammad Surjo Koentjoro $^{1}$, Firman Kurniawan Sujono ${ }^{2}$ \\ ${ }^{1}$ Program Pascasarjana Manajemen Komunikasi, Departemen Ilmu Komunikasi,Fakultas Ilmu Sosial dan Ilmu Politik, \\ Universitas Indonesia, Jakarta, Indonesia \\ ${ }^{2}$ Program Pascasarjana Manajemen Komunikasi, Departemen Ilmu Komunikasi, Fakultas Ilmu Sosial dan Ilmu Politik, \\ Universitas Indonesia, Jakarta, Indonesia
}

mochammad.surjo@ui.ac.id (Mochammad Surjo Koentjoro), firman.kurniawan09@ui.ac.id (Firman Kurniawan Sujono)

\begin{abstract}
As obligations go, the designing, writing and creating process of Corporate Annual Reports has always been viewed as something that is burdensome and exciting. It describes what the company has achieved during the last year, and the people creating it is under pressure to get all the details right. All the important and relevant information about the company need to be in the report and all must be presented correctly. The result is a book that is complete, comprehensive, but often very detailed and tedious to read. While that is the objective of the creating of the Corporate Annual Report, only few of the members of the organization are interested in reading it, thereby missing out on many important information,. This is despite Annual Reports were designed, created, and presented in a way that is as visually engaging as possible. The researcher's aim, using Observations and Literature Review was to investigate the role of Visual Aids in Corporate Annual Reports in drawing a wider internal audience.
\end{abstract}

Keywords: Annual Reports, Visual Aids, Organizational Communication

\section{Introduction}

A Public Company in Indonesia offering its stock to the investment community via public offering (otherwise known as "Emiten" or Issuer) needs to produce an Annual Report. This is based on a regulation issued by the Badan Pengawas Pasar Modal dan Lembaga Keuangan (Bapepam-LK) or the Capital Market and Financial Institutions Supervisory Agency, Bapepam LK Regulation No. X.K.6, August $1^{\text {st }}$, 2012, on the Submission of Issuer and Public Company Annual Report. Bapepam LK would later transform into Otoritas Jasa Keuangan (OJK) or Financial Services Authority.

According to XK6, a complete Annual Report must contain several important parts like: (1)

a) The Financial Overview

b) The Stocks Overview

c) The Management Report

d) The Management's Analysis on The Operational and Financial Performance of the company in the current year

e) Corporate Governance

f) Reports on Corporate Social Responsibility

g) Audited Financial Report as an attachment.

The main purpose of the Annual Report is to report to the General Meeting of Shareholders. (2)
However, the wealth of information available within an edition of Annual Report merits a study on the effects it might have on Organizational Communication.

\section{Problem Statement}

Despite the abundance of information contained within a Corporate Annual Report, relatively few members of the organization access it.

There was a survey conducted by RBC Direct in Canada in 2011 about investment information sources, whose data is used as a comparison (as a secondary data). In this study, which polls on where people get their research for online investing, only $12 \%$ of those surveyed used "mutual fund prospectuses or corporate annual reports". (3)

According to Mortrie R. Adams (2012), few people read Annual Reports. The reasons are because they are "hard to read", the photos are not "great", the copy or script are not fun to read, the whole edition was not engaging enough for the public, and they are not easily accessible. (4)

\section{Methodology}

One of the qualitative research methods in this study is observation. While working as a graphic designer involved in the production of Annual Reports the author studies the role of Visual Aids in the readership of them among the members 
of an organization. This parallels what was done by Hecht (1998) who works for one of the agencies that served the need of the street children he was studying in Northeast Brazil. According to Adler and Adler (1987), the author falls into the category of Active Membership with Active Participation. This role applies to individuals who take on some or all of the roles of core members. (5)

The design process that were observed were for Annual Reports that belong to

1) PT. Bank Mega, Tbk.

2) PT Semen Gresik, Tbk.

3) PT. Lippo Cikarang, Tbk

4) PT. Lippo Karawaci, Tbk

5) PT. Siloam International Hospitals, Tbk

6) PT. Gowa Makasar Tourism Development, Tbk

7) PT. XL Axiata, Tbk

By observing the design process of those Annual Reports that were written for the year of 2016, this paper aims to uncover qualitative insights on Annual Reports and the role of Visual Aids in it in the internal Organizational Communication.

The other research method employed is Literature Review, which is a survey of what other researchers have already done in the researcher's topic area. (6)

Using literature review, this paper surveys books, scholarly articles, and other sources relevant to this issue, and by so doing, provides a description, summary, and critical evaluation of these works in relation to this subject.

\section{Literature Reviews}

An Annual Report must contain at least the following: (2)

a) An overview of important financial data

b) Stock information (if any)

c) Reports from the Board of Directors

d) Reports from the Board of Commissioners

e) The profile of the issuer or public company

f) Analysis and discussion of managements

g) The governance of the issuer or public company

h) Social and Environmental Responsibility of the issuer or the public company

i) Audited Annual Financial Statements, Statements of members of the Board of Directors and Board members

Each part of the Annual Report has its own unique characteristics, and would provide certain information about the company.

The Financial Review, The Stocks Review, The Management Analysis, and The Financial Report deal with the finances of the company.

The Corporate Governance section mainly discusses legal aspects how the company was run by the management.

Another part of the Annual Report is the Corporate Social Responsibility section - which is closely related to the Corporate Governance section - explains the company's commitment in creating the balance between financial profit of the company and a harmony with the environment, be it social or natural environment. (1)

\subsection{Organizational Communication}

Communication in the context of an organization or organizational communication is defined as the display and interpretation of messages among communication units that are part of a particular organization. An organization is comprised of communication units in hierarchical relations to each other and functioning in an environment. (7)

\subsection{Types of Communicated Messages}

Messages may be displayed in verbal (involving language) or non-verbal (non-language) forms and by oral, written, or pictorial means. Both verbal and non-verbal displays are central to the functioning of an organizational communication system. (7)

Table 1. Examples of Types of Message
\begin{tabular}{|l|l|l|l|}
\hline & & Verbal & Non-verbal \\
\hline 1 & Oral & Interview & Speaking softly \\
\hline 2 & Written & Report & Diagram or layout \\
\hline 3 & Pictorial & Description of a scene & Sketch of a scene \\
\hline
\end{tabular}

According to Pace and Faules in the table above, there types of communication. Some of those types are used in an Annual Report.

The type of communication most used in an Annual Report is the Verbal-Written by which most of the description and explanation are done.

Annual Reports also uses the Verbal-Pictorial. By using photographs to report many activities of the company or activities of elements within the company, the company communicates with its public.

The other type of communication that is used is the NonVerbal-Written type. Information in the form of data and numbers, can often be better communicated via tables, diagrams, and infographics.

Judd and Tim (1991) reported in their research that it has been acknowledged that Annual Reports are the means by which companies communicate with their various publics. An Annual Report provides management with a unique opportunity to achieve several purposes. It can be a vehicle to communicate with customers, shareholders, employees, suppliers, media, and government.

In other words, An Annual Report is a media for management to communicate with its stakeholders. (8)

\subsection{The Stakeholders of an Organization}

Table 2. An Organization's Key Stakeholders and the Nature of Claims

\begin{tabular}{|l|l|l|}
\hline & Stakeholder Groups & \multicolumn{1}{|c|}{ Nature of Claims } \\
\hline 1 & Stockholders & Dividends, Capital Appreciation. \\
\hline 2 & Employees & $\begin{array}{l}\text { Wages, Benefits, Safe Working En- } \\
\text { vironment, Job Security. }\end{array}$ \\
\hline 3 & Supplies & $\begin{array}{l}\text { Payment on Time, Assurance of } \\
\text { Continued Relationship. }\end{array}$ \\
\hline 4 & Creditors & $\begin{array}{l}\text { Payment of Interest, Repayment of } \\
\text { Principal. }\end{array}$ \\
\hline 5 & Customers & Values, Warranties. \\
\hline 6 & Government & $\begin{array}{l}\text { Taxes, Compliance with Regula- } \\
\text { tions. }\end{array}$ \\
\hline 7 & Communities & $\begin{array}{l}\text { Good Citizenship Behaviour, Cor- } \\
\text { porate Social Responsibility. }\end{array}$ \\
\hline
\end{tabular}


According to Dess, et. al., (2010) in table 2 above, employees is among the stakeholders who have some claims on the company. (9)

In the book "A Theory of Human Motivation", Abraham Maslow (1943) wrote about the hierarchy of needs. (10)

For an employee of a company, those claims of benefits, wages, safe working environment and job security are his or her needs of safety. Attempts to seek safety and stability in the world are seen in the very common preference for familiar rather than unfamiliar things, or for the known rather than the unknown; as is the case in the work place.

Berger and Calabrese (1957) proposed the Uncertainty Reduction Theory, which stated that social life is filled with ambiguity, and individuals use communication to minimize their doubts.

According to the Uncertainty Reduction Theory, there are three strategies an individual can seek ways to reduce uncertainty, the passive strategy, the active strategy, and the interactive strategy. (11)

In the passive strategy, an individual (an employee) waits and pays attention until a relevant information comes his or her way.

In an active strategy he or she seeks information from what resources available for him or her. This should include the latest edition of the Corporate Annual Report in which he or she could learn about the company's performance in terms of Finance or Management. He or she could learn more about the Vision and Mission of the company, the goals and objective of the company, the plans made by the management. All those information could help reducing his or her uncertainty, thus help fulfilling his or her needs of safety.

And it should be noted that all important messages of Annual Reports are presented prominently and aesthetically designed to ensure the visibility of the message.

Figure 1. Introduction page from the PT. Semen Gresik, Tbk.’s 2016 Annual Report

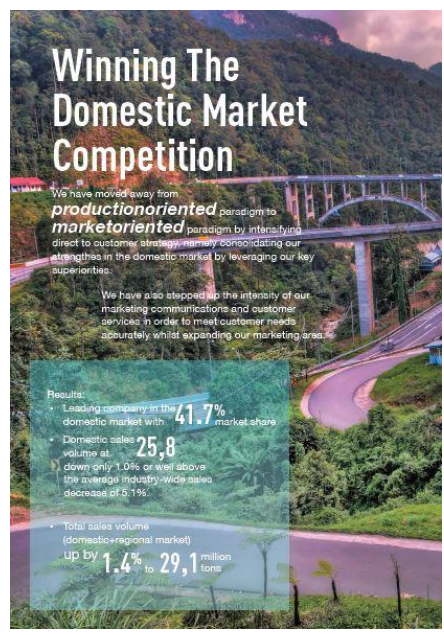

In the sample above, the company is states what it considers its most important achievement which is "Winning the Domestic Market Competition" written as the title of the page followed by more detailed description. (12)
The tone of optimism of the whole message should give an employee of the company a measure of safety.

In the interactive strategy, an employee would directly pose questions to the members of the management.

Non-verbally, the use of a particular style, design, corporate colour palette, and logo on the Annual Report, which the employees can also see on their uniforms, business stationeries, buildings and vehicles, can also strengthen the sense of belonging.

These visual aids can increase audience (readers) comprehension and retention. Visuals reinforce and help communicate the speaker's (sender's) message, enabling receiver to understand what words alone cannot transmit. (13)

\subsection{Visual Aids}

Based on the observation by the author, the process of putting together an Annual Report includes the heavy use of Graphic Design as a Visual Aid.

According to Ruben and Stewart (2006), Visual Aids function to add interest to a presentation (in this case, an Annual Report) by giving the audience (readers) something to examine. They may also clarify what the sender is saying (writing) by providing a visual illustration to the points being made. (14)

There are four types of visual aid that help public communicators convey their messages to large audiences:

1. The actual object being discussed, the presenter uses the actual object being discussed.

2. A model of the object, the presenter uses a model of the real object being discussed.

3. Mediated objects, such as pictures or movies.

4. Mediated models, such as charts, graphs, and diagrams.

Annual Reports use type 3 and 4 of the visual aids described above.

\subsection{Internal Organization Communication (Thayer)}

Technically, internal communication is a communication process which involves organization's members as recipients of messages. (15)

According to Thayer (1968), and made more popular by Greenbaum (1974) there are four basic objectives of organizational communication messages: to inform, to persuade, to regulate, and to integrate. (15)

\subsubsection{Communication's Information Function}

This function of communication helps an individual to reduce the environmental uncertainty through adaptation. For an employee, more information could help give him more understanding about the company, the kind of work he does, the people he works for. He can also gain insights on what are his works objectives, targets, and the challenges in reaching those goals. In short, information serves as adaptive and innovative function.

The Annual Report provides all those which will be relevant for at least one year.

Below is a sample of a Table of Contents of an Annual Report, presented with the use of Graphic Design as a Visual Aid, with the goal to make it more interesting. 
In this case, the chapters are:

a) Profile of the Company

b) Management Analysis and Discussion

c) Operational Review

d) Corporate Governance

e) Corporate Social Responsibility

f) Audited 2016 Financial Report

Figure 2. Table of content of PT. Bank Mega, Tbk.'s 2016 Annual Report (16)
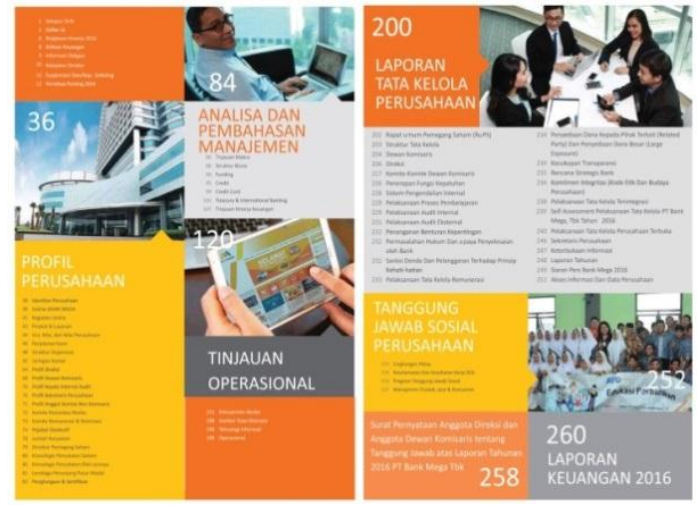

It uses compositions of rectangles in different colours, shapes, and proportions to divide the page and "house" the chapters. The detailed sub-chapters and texts of corresponding pages are housed in one some of the boxes.

The Chapters can also be represented or complemented with photos. The images in this page can be a photo documentation of the company's social activities. The photo can also be some assets of the company, like the Company Headquarters, the Company's operational vehicle.

Narration as a means of achieving a desired interpretation was augmented by photography (Anderson and Imperia, 1992, Douglas, 2000). The use of images can provide a guide to direct interpretations to particular ideas. (8)

For example, the use of photographs to present the company's Corporate Social Responsibility activities, to shape the perception about the company's social commitments.

Figure 3. A photo of a Corporate Social Responsibility activity in an Annual Report

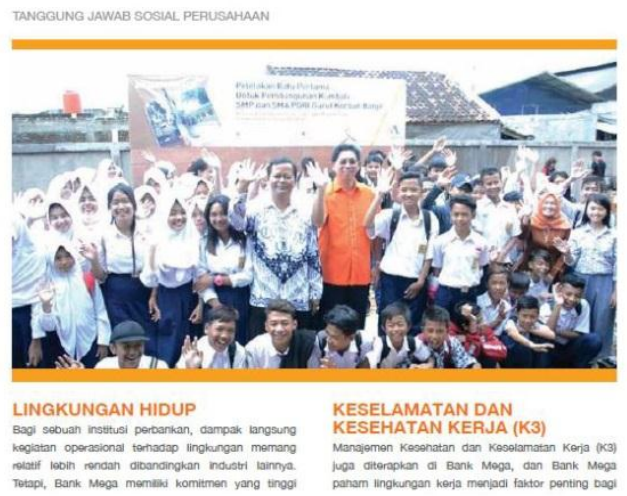

Studies by Beattie and Jones (1999) also have shown that the use of financial graphs was another of the device used by the management to enhance the perception of their performance. (8)

Figure 4. The use of financial graph to enhance the perception of the performance of the company

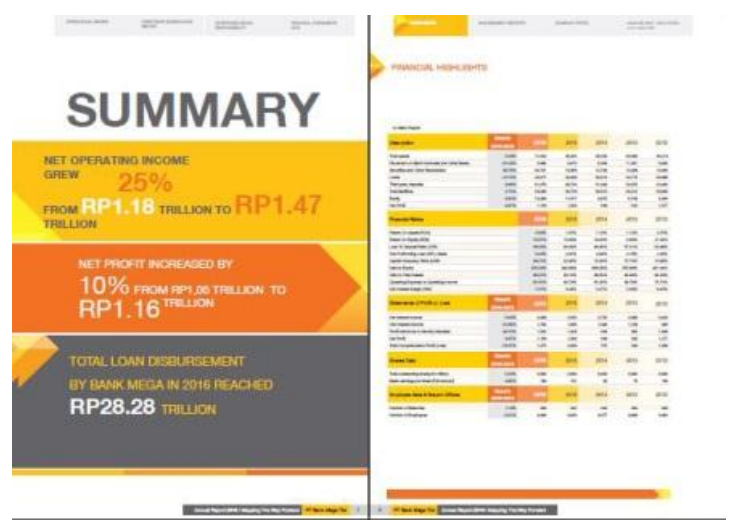

4.5.2. Communication's command and instructive function

This function enables the management to get the employees to work in sync with the company's goals and objectives. This function concerns with the employees' compliance to rules, standardized work practices, procedures, and work result criteria.

Annual Repots do not have a very important role in this function due to their nature as media to report the performance of the company and the conducts of the management during the previous year.

\subsubsection{Communication's influence and persuasive func-} tion

Through influence and persuasion, the management with its position and authority could control information and behaviour of the employees by using sets of rules, norms, and responsibility.

If an employee reads the Corporate Governance and the About the Corporation sections of the Annual Report, then he will be able to see the broader view of his or her environment, and finds his or her position within the organization, and can be motivated to work better to achieve his or her targets.

The use of motivating slogans as the title of the Annual Report can influence an employee's motivation to work better.

\subsubsection{Communication's integration function}

Communication helps creating harmony among all members of an organization, so that everybody can work together to reach the objectives of the organization. It is related to the functional formal communication but also relational and social.

With messages in the Company's Profile, Vision and Mission, and Corporate's Values sections which can motivate the employees and builds the sense of belonging.

Lipton (1996) wrote that Vision is organizational goals that evoke powerful and compelling images, goals that are 
"massively inspiring, overarching, and long term. The vision statement may also contain a slogan, diagram, or picture "whatever grabs attention" (9)

Mission statement is a set of organizational goals that include both the purpose of the organization, its scope of operations, and the basis of its competitive advantage. (9)

Below are the Vision, Mission, and Values statements written in the 2016 Annual Report of PT. Lippo Cikarang, Tbk.

1. Vision: "To build a comprehensive township and to create a conducive place to live, work and lifestyle."

2. Mission: "To be Indonesia's premier industry, commercial and residential based urban developer by means of investing in infrastructure, public facilities and town management components to maintain high entry market levels, high added value, high margins and strong competitive advantage in business."

It was declared the Vision and Mission was officially approved during a joint meeting between Board of Commissioners and Board of Directors on a certain date. (17)

3. Values: "Customer Focus", "Commitment to Excellence and Goals", "Integrity", "Innovation", "Teamwork", "Spirit of Learning".

According to Peter Senge in "The Fifth Discipline: The Art and Practice of the Learning Organization" (1990), Shared Values is one of the discipline that needs to be developed. The development of a shared vision is important in motivating the staff to learn, as it creates a common identity that provides focus and energy for learning. And a learning organization develops as a result of the pressures facing modern organizations and enables them to remain competitive in the business environment. (15)

One step to develop a Shared Vision among employees is by shortening the distance between them. People's distance from a source can have a major influence on the likelihood of their attending to a particular message. People are more likely to be exposed to sources that are closer in proximity. (14)

\subsection{Laswell's View of Communication}

In the basic and broad sense, as media of communication, Annual Reports' nature is a one way model, and can be examined using Harold Laswell's perspective. Laswell (1948) said that communication process could be best explained by the simple statement: "Who says what to whom in what channel with what effect". (14)

Figure 5. Laswell's Model

$\begin{aligned} & \begin{array}{l}\text { Who? } \\ (\text { Sender })\end{array} \\ & \text { Says what? } \\ & \text { (Message) }\end{aligned}, \begin{aligned} & \text { What channel? } \\ & \text { (Medium) }\end{aligned}, \begin{aligned} & \text { To whom? } \\ & \text { (Receiver) }\end{aligned}$, Effect

In the case of Annual Reports, the Sender is the management of the company, which are the Board of Commissioners and the Board of Directors. The Message is essentially a report on what the Management has been doing during the year and the results.

The media or channel used primarily is a report of Overviews, Reports and Analysis on the state and progress of the company. They are all compiled into a book that is usually several hundred pages thick, and professionally done in terms of packaging and design. It is also available online (on the internet) and in digital format, in a USB Flash Drive or DVD-ROM.

The intended receiver of the message and the intended effects are:

1. The Regulators (OJK), to prove that the company is being run according to the rules and regulations of the country.

2. The Shareholders, the show that the company is being run to the best interest of the company and according to the rules of the company.

Graham Kenny (2014) wrote that several key components that concerns employees that are missing in most Annual Reports. What are the productivity and employee retention numbers? On the other side of this two-way street, what does employee satisfaction look like?

In industries such as mining, employee safety is now reported in detail, through an injury frequency rate. Companies are making some progress in their reporting but we are still missing those comprehensive scorecard. (18)

Based on the author's observations, some of Graham Kenny's claims are true. While employee safety records and employee retention numbers are reported, employee satisfaction is not.

\subsection{Organizational Information Theory (Weick)}

Examination of Annual Reports as media of information can be done using the study of Organizational Information Theory, which was largely based on studies done by Karl Weick. (7)

Weick (1979) states that the word organization is a noun, and it is also a myth. Organization is made up of events that are linked together. In other words, organization is processdriven rather than structurally driven. Human beings face a complex and uncertain environment, which Weick maintains is the reason for organizing. Organizing come into being because organizing activity is necessary to combat the ambiguity and uncertainty that human face. Organization must manage this equivocality, and they do so by giving meaning to events.

Organizational members accomplish this sense making process through enactment, selection, and retention of information. (19)

Organizations are successful to the extent that they are able to reduce equivocality through these means.

1. Enactment

It means the role of action. Individuals with data and knowledge refines and actualizes ideas through trial and error. Enactment helps to define the meaning, helping members of the organization to be in control of their environment.

2. Selection

This includes evaluation of outstanding information necessary to further reduce equivocality. 
At this stage, the decision makers of the organization plays an important part.

3. Retention

It is the keeping and retaining the information that has proven to be useful and beneficial, to be applied on future projects.

This theory explains the model of communication between an organization interacting with the environment, almost as if it is a living organism. But it also attempts to explain the behaviour of the organization's member in its activities in interacting with each other, with the organization, and as the part of organization in interacting with the environment.

In this sense, Annual Reports can be a part of the whole process as the media of presenting the selected and retained information to be a reference in the process of enactment. But only a part of it since there are other factors involved in this process of managing equivocality because according to this theory, organization is something that is process driven and made up of events, so it is constantly changing.

\section{Conclusion and Discussion}

The use of Visual Aids helps the presentation of Annual Reports, but only to a certain extent. There are factors that are beyond the capability of Visual Aids in attracting the readership among members of the organization. But Visual Aids do have its purpose and can also be useful in other media of internal organization communication like the Internal Bulletin or Intranet.

Annual Reports' lack of readership among members of the organization can be explained by Laswell's view of Communication that it was put together to comply with the Rules and Regulations, and not customized to the information needs of the organization members.

Weick's assertion that organization was in fact made up of processes instead of structures and thus constantly changing and developing, has further limits the functionality of Annual Reports among members of the organization.

Despite the limitation of what Visual Aids can do to help Annual Reports reach wider audience internally, the fact remains that Annual Reports are produced and done professionally. Due to its contents, it can be seen as representing the management of the company, in the way it is governed, and the way it performs.

Further research needs to be done to accurately measure the Role of Visual Aids in Drawing Wider Audience Internally.

\section{ACKNOWLEDGEMENT}

This study was made possible due to the author's opportunity to observe the process of putting together some Corporate Annual Report while participating in the design processes at the PT. Voleti Media Kreasi.

\section{REFERENCES}

[1] Annual Report, Laporan Keuangan dan Kebijakan OJK, August $10^{\text {th }}, 2016$, retrieved from http://annualreport.id/kiatstrategi/annual-report-laporan-keuangan-dan-kebijakan-ojk

[2] Peraturan Otoritas Jasa Keuangan Nomor 29/POJK.04/2016, retrieved from http://www.ojk.go.id/id/kanal/pasarmodal/regulasi/peraturan-ojk/Documents/Pages/POJKLaporan-Tahunan-Emiten-Perusahaan-Publik/POJKLaporan-Tahunan.pdf

[3] Jones, Dominic, "More evidence that few actually read annual reports." 2011, retrieved from http://irwebreport.com/20110713/few-read-annual-reports/

[4] Adams, Mortrie R., “Annual Reports... Who reads them?”, January $18^{\text {th }}, 2012$, retrieved from http://www.visibilitymarketing.com/2012/01/annual-reports-who-reads-them/

[5] DeWalt, Kathleen M., and DeWalt, Bille R., Participant Observation, A Guide for Field Worker, $2^{\text {nd }}$ edition, 2011, AltaMira Press.

[6] Baxter, Leslie A., and Babbie, Earl, The Basics of Communication Research, 2004, Thomson Wadsworth.

[7] Pace and Faules, Organizational Communication, $3^{\text {rd }}$ ed, 1994, New York: Prentice Hall.

[8] Stanton, Patricia A., and Stanton, John, Researching Corporate Annual Reports: An Analysis of Perspectives Used, Department of Accounting and Finance and School of Management, Faculty of Economic and Commerce, University of Newcastle, Newcastle, N.S.W. Australia 2308.

[9] Dess, Lumpkin, and Eisner, 2010, Strategic Management, Text and Cases, $5^{\text {th }}$ ed., New York: McGraw-Hill.

[10] Maslow, Abraham H., A Theory of Human Motivation, Psychological Review, 50, 370-396, 1943.

[11] Dainton, Marianne, and Zelley, Elaine D., Applying Communication Theory for Professional Life, A Practical Introduction, 2011, SAGE Productions, Inc.

[12] “Winning the Market Through Transformation”, PT. Semen Gresik, Tbk. 2016 Annual Report, 2017.

[13] Gamble, Teri Kwal, and Gamble, Michael, Communication Works, Eighth Edition,2005, New York: McGraw-Hill.

[14] Ruben, Brent D., and Stewart, Lea P., Communication and Human Behavior, Fifth Edition, 2006, Pearson.

[15] Hardjana, Andre, Komunikasi Organisasi, Strategi dan Kompetensi, 2016, Jakarta: Penerbit Buku Kompas.

[16] “Mapping the Way Forward”, PT. Bank Mega, Tbk 2016, Annual Report, 2017.

[17] “Creating Global Communities”, PT. Lippo Cikarang, Tbk. 2016 Annual Report, 2017.

[18] Kenny, Graham, "What's missing from an Annual Report?", December $19^{\text {th }}, 2014$, retrieved from https://hbr.org/2014/12/whats-missing-from-annual-reports.

[19] West, Richard, and Turner, Lynn H., Introducing Communication Theory, Analysis and Application, Fourth Edition, 2010, New York: McGraw Hill. 